\title{
Phanerochaete Chrysosporium Loaded Cryogel Column for Biosorption of Mercury (II) Ions from Aqueous Solutions
}

\author{
Sulu Çözeltilerden Civa Biyosorpsiyonu için Phanerochaete \\ Chrysosporium Yüklü Kriyojel Kolon
}

\author{
Research Article
}

Kemal Çetin', Deniz Türkmen', Tahira Qureshi', Necdet Sağlam² and Adil Denizlii*

'Department of Chemistry, Biochemistry Division, Hacettepe University, Ankara, Turkey.

2Institute of Science, Department of Nanotechnology and Nanomedicine, Hacettepe University, Ankara, Turkey.

\section{A B S T R AC T}

\begin{abstract}
The focus of present study was to evaluate the potential of Phanerochaete chrysosporium loaded monolithic composite cryogel columns for the removal of $\mathrm{Hg}^{2+}$ ions from aqueous environments. The swelling degree of the composite column was $6.68 \mathrm{~g} \mathrm{H}_{2} \mathrm{O} / \mathrm{g}$ whereas the plain cryogel column was observed as $7.12 \mathrm{~g} \mathrm{H}$ Optimum working conditions for the column were determined. The reuse of the column was investigated and the results showed that this specific column can be used heaps of times with observing no decrement the $\mathrm{Hg}^{2+}$ biosorption capacity significantly. Synthetic wastewater studies were also applied and the biosorption capacity for $\mathrm{Hg}^{2+}$ was $75.22 \mathrm{mg} / \mathrm{g}$.
\end{abstract}

\section{Key Words}

Biosorption, cryogel, heavy metals, $\mathrm{Hg}^{2+}$ ions, Phanerochaete chrysosporium.

\section{ÖZET}

u çalışmanın amacl, Phanerochaete chrysosporium yüklü mololitik kompozit kriyojel kolonlarla sulu ortamlardan $\mathrm{Hg}^{2+}$ iyonlarının uzaklaştırılma potansiyelini araştırmaktır. Yüklü olmayan kolonun şişme derecesi $7.12 \mathrm{~g} \mathrm{H}_{2} \mathrm{O} / \mathrm{g}$ iken kompozit kolonun şişme derecesi $6.68 \mathrm{~g} \mathrm{H}_{2} \mathrm{O} / \mathrm{g}$ 'dır. Kolonun optimum çalışma koşulları belirlenmiştir. Kolonun tekrar kullanılabilirliği incelenmiş ve sonuçlar bu özgül kolonun $\mathrm{Hg}^{2+}$ biyosorpsiyon kapasitesinde önemli bir azalma gözlenmeden defalarca kullanılabileceğini göstermiştir. Yapay atık su çalışmaları da uygulanmış ve bu sistem için $\mathrm{Hg}^{2+}$ için biyosorpsiyon kapasitesi $75.22 \mathrm{mg} / \mathrm{g}$ olarak bulunmuştur.

\section{Anahtar Kelimeler}

Biyosorpsiyon, kriyojel, ağır metaller, $\mathrm{Hg}^{2+}$ iyonları, Phanerochaete chrysosporium.

Article History: Received: Jan 10, 2016; Revised: Mar 20, 2016; Accepted: Mar 20, 2016; Available Online: Apr 01,2016 DOI: $10.15671 /$ HJBC.20164417568

Correspondence to: A. Denizli, Department of Chemistry, Biochemistry Division, Hacettepe University, Ankara, Turkey. 


\section{INTRODUCTION}

ne of the most toxic heavy metals, mercury is released to the environment via natural events and industrial activities [1]. It can accumulate into human body through food chain and can cause serious health problems [2]. Mercury mainly damages nervous system, reproduction and immune response, and can cause liver and kidney impairments [3].

Due to the serious ecological and health effects of mercury, number of methods such as precipitation-neutralization, reverse osmosis, ultra-filtration, solvent extraction, electrodeposition etc., have been introduced to remove mercury from wastewater [4]. As an alternative to the conventional methods, biosorption is an assuring method to remove heavy metals from wastewater [5]. Biosorption is a passive process of metal ion binding by dead or living biomass such as magnetic yeast cells [4], fungi, bacteria, molds, seaweeds and crab shells $[6,7]$. The use of dead biomass has some preferences over living ones, such as less sensitive to heavy metal ion concentrations and medium conditions (ie, temperature and $\mathrm{pH}$ ), no need nutrition and controlling of concentration of biomass [7-9].

Cryogels are 3D macroporous polymeric matrices produced at subzero temperatures [10] Cryogelation starts with that the monomeric or polymeric precursors form cross-linked gel in unfrozen or moderately frozen phases while aqueous phase produces ice crystals under frozen conditions. After cryogelation, ice crystals are thawed at room temperature (RT) and macroporous structure is obtained [11]. In cryogelation step, the polymerization phase concentrate in a small volume due to growing ice crystals and it provides formation of thick pore walls which results in a mechanically stable and sturdy structure [12].

Herein, poly(hydroxyethyl methacrylate) [PHEMA] based composite cryogel loaded with a white rot fungus, $P$. chrysosporium was produced for efficient biosorption of $\mathrm{Hg}^{2+}$ ions from aqueous solutions. $P$. chrysosporium powder was added into monomer solution of hydroxyethyl methacrylate (HEMA), and PHEMA monolithic column was prepared via cryogenic treatment. Plain PHEMA cryogel (i.e. non-loaded with the fungus) was also synthesized as control group. Cryogels can be good candidate as biosorbents in biochromatography because of some effective features such as supermacropores of the cryogel matrix, low pressure drop, short diffusion path, and short residence time [13-15]. The effect of $\mathrm{pH}$ on biosorption capacity was investigated by measuring the biosorption of $\mathrm{Hg}^{2+}$ ions on the inactivated fungus loaded PHEMA cryogel at different $\mathrm{pH}$ values. The maximum biosorption capacities of both $P$. chrysosporium loaded and plain PHEMA cryogel columns were studied by changing the concentrations of $\mathrm{Hg}^{2+}$ ions in the aqueous solutions.

\section{Experimental}

\section{Materials}

White-rot basidiomycete, Phanerochaete chrysosporium ME446 strain (ATCC-3454) was obtained from Hacettepe University, Science Faculty, Department of Biology, Biotechnology Division (Ankara, Turkey). Malt Extract Agar was obtained from Merck AG (Darmstadt, Germany). HEMA and $\mathrm{N}-\mathrm{N}^{\prime}$ - methylene-bisacrylamide (MBAAm) were purchased from Fluka A.G. (Buchs, Switzerland). N,N,N',N'-tetramethyl ethylene diamine (TEMED) and ammonium persulfate (APS) were purchased from Fluka (Buchs, Switzerland). All other chemicals were of reagent grade and were provided from Merck AG (Darmstadt, Germany). Water used in all the studies was purified and deionized by a Barnstead D3804 NANOpure ${ }^{\circledR}$. Buffer systems and sample solutions were filtered through $0.2 \mu \mathrm{m}$ membrane (Sartorius, Göttingen, Germany). Before use, all glassware were extensively washed with dilute nitric acid.

\section{Microorganism and Growth Conditions}

Culture of $P$. chrysosporium (strain ATCC 446) was maintained on supplemented malt agar slants. Growth medium was made up of (in $\mathrm{g} L-1$ of distilled water); D-glucose, 10.0; malt extract, 10.0; peptone, 2.0; yeast extract, 2; thiamin- $\mathrm{HCl}, 0.001$; $\mathrm{KH}_{2} \mathrm{PO}_{4}, 2.0 ; \mathrm{MgSO}_{4} .7 \mathrm{H}_{2} \mathrm{O}$, 1; agar, 20. Spores were prepared by suspention in steril Water and Spore Production in the slants usually requires 
3-5 days of growth at $39^{\circ} \mathrm{C}$. The growth medium was supplemented with $1.0 \mathrm{~mL}$ of trace element solution (containing $\mathrm{g} / \mathrm{L}$ of distilled water); $\mathrm{MgSO}_{4} .7 \mathrm{H}_{2} \mathrm{O}, 3.0 ; \mathrm{Na}_{2} \mathrm{MoO}_{4} .2 \mathrm{H}_{2} \mathrm{O}, 0.01 ; \mathrm{MnSO}_{4}$. $\mathrm{H}_{2} \mathrm{O}, 0.5 ; \mathrm{NaCl}, 1.0 ; \mathrm{H}_{3} \mathrm{BO}_{3}, 0.01 ; \mathrm{FeSO}_{4} \cdot 7 \mathrm{H}_{2} \mathrm{O}$, 0.1 ; nitrilotriacetate, $\mathrm{CoCl}, 0.1 ; \mathrm{ZnSO}_{4} \cdot 7 \mathrm{H}_{2} \mathrm{O}, 0.1$; AlK $\left(\mathrm{SO}_{4}\right)_{2} \cdot 12 \mathrm{H}_{2} \mathrm{O}, 0.01 ; \mathrm{CuSO}_{4} \cdot 5 \mathrm{H}_{2} \mathrm{O}, 0.1$. Stock culture of $P$. chrysosporium suspended in $5.0 \mathrm{~mL}$ distilled water and transferred into $500 \mathrm{~mL}$ flask containing $100 \mathrm{~mL}$ of malt extract broth, and the flasks were incubated on an orbital shaker (140 rpm) for 7 days at $30^{\circ} \mathrm{C}$. After this process, the microorganisms were obtained from the medium by filtration and washed with purified water a couple of times. Then the biomass was kept in an oven to dry at $90^{\circ} \mathrm{C}$ for $24 \mathrm{~h}$. Finally, the biomass was grinded in a grinder and the fungus powder was obtained.

\section{Preparation of Phanerochaete chrysosporium Loaded Cryogel Columns}

Precisely, the cross-linker MBAAm $(0.3 \mathrm{~g})$ was dissolved in $12.0 \mathrm{~mL}$ of purified water and the main monomer HEMA (1.3 mL) was added into this solution. Then, the mixture was degassed and kept in an ice bath for $10 \mathrm{~min}$. At this stage, fungus particles (i.e. Phanerochaete chrysosporium) were added to the mixture with vigorous stirring. The amount of loaded fungus was varied in the range of 50-250 mg. Free radical polymerization initiated by APS and TEMED was used in order to produce cryogel columns. APS ( $20 \mathrm{mg}, 1 \%(\mathrm{w} / \mathrm{v})$ of the total monomers) was added into the solution in the ice bath. After $2-3$ min., TEMED $(25 \mu \mathrm{L}, 1 \%$ $(\mathrm{w} / \mathrm{v})$ of the total monomers) was added and the solution was stirred for $1.5 \mathrm{~min}$. Subsequently, the polymerization solution was transferred into plastic syringes $(5 \mathrm{~mL}$, id. $0.8 \mathrm{~cm}$ ) whose bottom was closed. The syringes containing the monomer solution was kept in frozen state at $-16^{\circ} \mathrm{C}$ for 24 $\mathrm{h}$ and afterwards thawed to r.t. Then the cryogel columns were washed with $150 \mathrm{~mL}$ of water and stored in buffer including $0.02 \%$ sodium azide $\left(\mathrm{NaN}_{3}\right)$ at $4^{\circ} \mathrm{C}$ until use.

\section{Characterization of Cryogel Columns}

The specific surface area of cryogel columns in dry state was analyzed by Brunauer-Emmett-Teller (BET) with an analyzer (Quantachrome, NOVA 2000, USA). Cryogels (1.0 g) placed in a sample holder and degassed using $\mathrm{N}_{2}$-gas at $150^{\circ} \mathrm{C}$ for 1 h. Adsorption of the gas was performed at $-210^{\circ} \mathrm{C}$ and desorption was applied at RT. Data obtained from desorption step were used for the specific surface area calculation.

To determine the swelling degree (S) of cryogel columns, each sample was dried to constant weight $\left(\mathrm{W}_{\mathrm{o}^{\prime}} \mathrm{g}\right)$ and then soaked in distilled water in an isothermal water bath $\left(25 \pm 0.5^{\circ} \mathrm{C}\right)$ for $2 \mathrm{~h}$. Then, the swollen cryogel columns were removed from water, carefully wiped using a filter paper, and weighed $\left(W_{s}, g\right)$. The equilibrium mass swelling degree was calculated by the following equation:

$\mathrm{S}=\left(\mathrm{W}_{\mathrm{s}}-\mathrm{W}_{\mathrm{o}}\right) / \mathrm{W}_{\mathrm{o}}$

The total volume of macro-pores in the swollen cryogel matrix was roughly estimated by the following equation:

Macroporosity $(\%)=\left[\left(\left(W_{1}-W_{2}\right)\right) / W_{1}\right] \times 100$

where $W_{1}$ and $W_{2}$ are fully swollen gel and squeezed gel weights (g), respectively.

The surface morphologies of the cryogel columns were investigated using a scanning electron microscope (SEM). The frozen cryogels were lyophilized and then mounted on a SEM sample holder and sputtered for gold film coating for 2 min. The surface of cryogels was scanned at desired magnification to study the wall morphology of cryogels in a SEM (Jeol Ltd., JSM 5600, Tokyo, Japan).

\section{$\mathrm{Hg}^{2+}$ Biosorption Studies}

To optimize the biosorption capacity of composite cryogel column, the prepared $\mathrm{Hg}^{2+}$ ion solutions were passed through the cryogel column using a peristaltic pump. Effects of the loading amount of fungus, equilibrium $\mathrm{Hg}^{2+}$ concentration, medium $\mathrm{pH}$ and flow-rate on the biosorption rate and capacity were examined. As a source of $\mathrm{Hg}^{2+}$ ions, nitrate salt was used. The concentrations of the $\mathrm{Hg}^{2+}$ ions in the aqueous solution were determined using a flame atomic absorption spectrophotometer (Shimadzu Model AA-6800 Flame, Japan). Deuterium background correction 
was performed during the experiments. The instrument response was periodically controlled with a known $\mathrm{Hg}^{2+}$ standard solution. All the biosorption experiments were done in replicates of three and the sample solutions were analyzed in replicates of three as well. For each set of data given, standard statistical methods were performed to find the mean values and relative standard deviations. Confidence of intervals at 95\% were calculated for each set of data in order to find the margin of error. The amount of metal biosorption per unit mass of the cryogel was calculated using the concentration difference.

\section{Regeneration and Reuse}

Elution of $\mathrm{Hg}^{2+}$ ions from the P. chrysosporium loaded cryogel column was performed as follows; $50 \mathrm{~mL}$ of $0.1 \mathrm{M} \mathrm{HNO}_{3}$ solution as elution agent was pumped through the cryogel column at a flow rate of $1.0 \mathrm{~mL} / \mathrm{min}$ for $3 \mathrm{~h}$ at RT. The final mercury ion concentrations in the solution was found by using a flame furnace atomic absorption spectrophotometer. The elution ratio was measured from the amount of $\mathrm{Hg}^{2+}$ ions biosorbed on the column and the final concentration of $\mathrm{Hg}^{2+}$ ions in the elution medium. In order to test the reusability of the cryogel column, biosorptionelution cycles were repeated 10 times by using the same composite column.

\section{Heavy Metal Biosorption from Artificial Wastewater}

Biosorption of heavy metal ions was studied from synthetic wastewater including $1.0 \mathrm{mmol} / \mathrm{L}$ of $\mathrm{Hg}^{2+}, \mathrm{Cu}^{2+}, \mathrm{Ni}^{2+}, \mathrm{Zn}^{2+}, \mathrm{Fe}^{3+}, \mathrm{CO}^{2+}, \mathrm{Cd}^{2+}, \mathrm{Cr}^{3+}$ and $\mathrm{Al}^{3+}$ Salinity of the synthetic wastewater was adjusted with $\mathrm{NaCl}$ (700 ppm). After biosorption, the concentration of the metal ions in the remaining solution was found via a flame furnace atomic absorption spectrophotometer as described above.

\section{Results and Discussion}

\section{Characterization Studies}

A supermacroporous cryogel column was fabricated via cryogelation in the moderately frozen state of monomers and polymer precursors. Before the cryogelation, Phanerochaete chrysosporium were added to the monomer solution. The SEM images of the internal structure of the cryogel matrix are presented in Figure $1 a$. As seen in the figure, the cryogel column has large supermacropores (up to $100 \mu \mathrm{m}$ ) and flow channels which allow the effective migration of solute molecules in aquatic system. Early studies showed that flow of mobile phase were performed by both convection and diffusion in cryogel matrix [12]. Moreover, solute molecules are primarily transported via convective transport in cryogels unlike it is mainly diffusion in hydrogels [12]. Therefore, the mass transfer resistance is negligible [16]. Because cryogels have large flow channels, and so, generate very little backpressure, it is possible to work at high flow rates with the cryogel columns. When the squeezed cryogel was immersed in distilled water, it filled with water and within 1-2 s came back its original size and shape. The equilibrium swelling degree was $6.68 \pm 0.32 \mathrm{~g} \mathrm{H}_{2} \mathrm{O} / \mathrm{g}$ for the $P$. chrysosporium loaded PHEMA and $7.12 \pm 0.15 \mathrm{~g} \mathrm{H}_{2} \mathrm{O} / \mathrm{g}$ for the plain PHEMA cryogels (Table 1). Compared with the plain cryogel, the equilibrium swelling degree of composite cryogel was decreased owing to the incorporation of solid fungus particles. As depicted in Figure $1 \mathrm{~b}$, the macroporosity measurements were calculated based on the ratio of the weight difference of reswollen and initial fully swollen cryogel to initially fully swollen cryogel. Cryogel column presents high macroporosity values as discussed in Table 1.

\section{Biosorption of $\mathrm{Hg}^{2+}$ Ions}

\section{Effect of Loaded Fungus Amount}

The $\mathrm{Hg}^{2+}$ ion adsorption capacities of the $P$. chrysosporium loaded PHEMA cryogel column with different loaded fungus amounts are presented in Figure 2. It was observed that $\mathrm{Hg}^{2+}$ ion adsorption capacity of the fungus loaded column was improved significantly because of the loaded fungus amount up to $100 \mathrm{mg}$. Then, the slope of adsoption raise decreases significantly because it reached a saturation level. The further increase in the loading amount may have resulted in the decrease of surface area of composite cryogel column.

Effect of Equilibrium Concentration of $\mathrm{Hg}^{2+}$ Ions The effects of equilibrium concentration of $\mathrm{Hg}^{2+}$ 
a
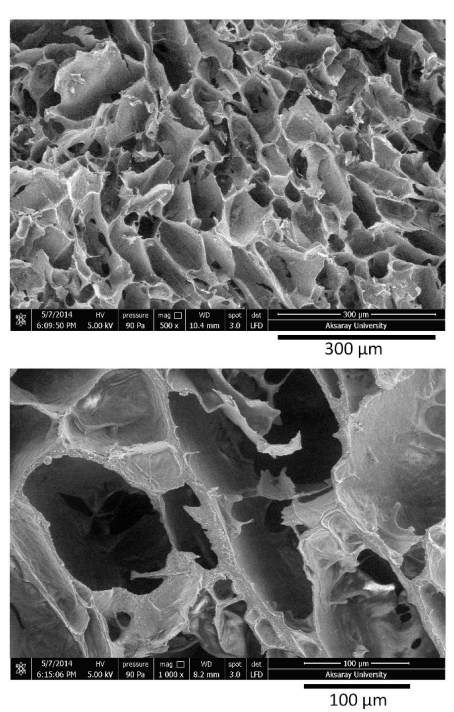

b

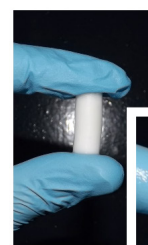

initial fully swollen cryogel
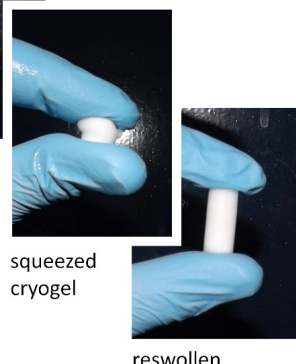

reswollen

cryoge

Figure 1. (a) SEM images of the monolithic cryogel column. (b) The optical images of initial fully swollen, squeezed and reswollen cryogel.

Table 1. Physical properties of monolithic cryogel columns. ${ }^{a}$

\begin{tabular}{cccc}
\hline Polymer & Surface area $\left(\mathrm{m}^{2} / \mathrm{g}\right)$ & Swelling degree $\left(\mathrm{g} \mathrm{H}_{2} \mathrm{O} / \mathrm{g}\right)$ & Macroporosity $(\%)$ \\
\hline $\begin{array}{c}\text { P. chrysosporium loaded } \\
\text { PHEMA }\end{array}$ & $16.1( \pm 0.78)$ & $6.68( \pm 0.32)$ & $7.12( \pm 0.15)$ \\
\hline Plain PHEMA & $14.2( \pm 0.28)$ & $7.12( \pm 0.15)$ & $80.2( \pm 0.78)$
\end{tabular}

${ }^{a}$ Numbers in the parenthesis show the standard deviation for $n=3$.

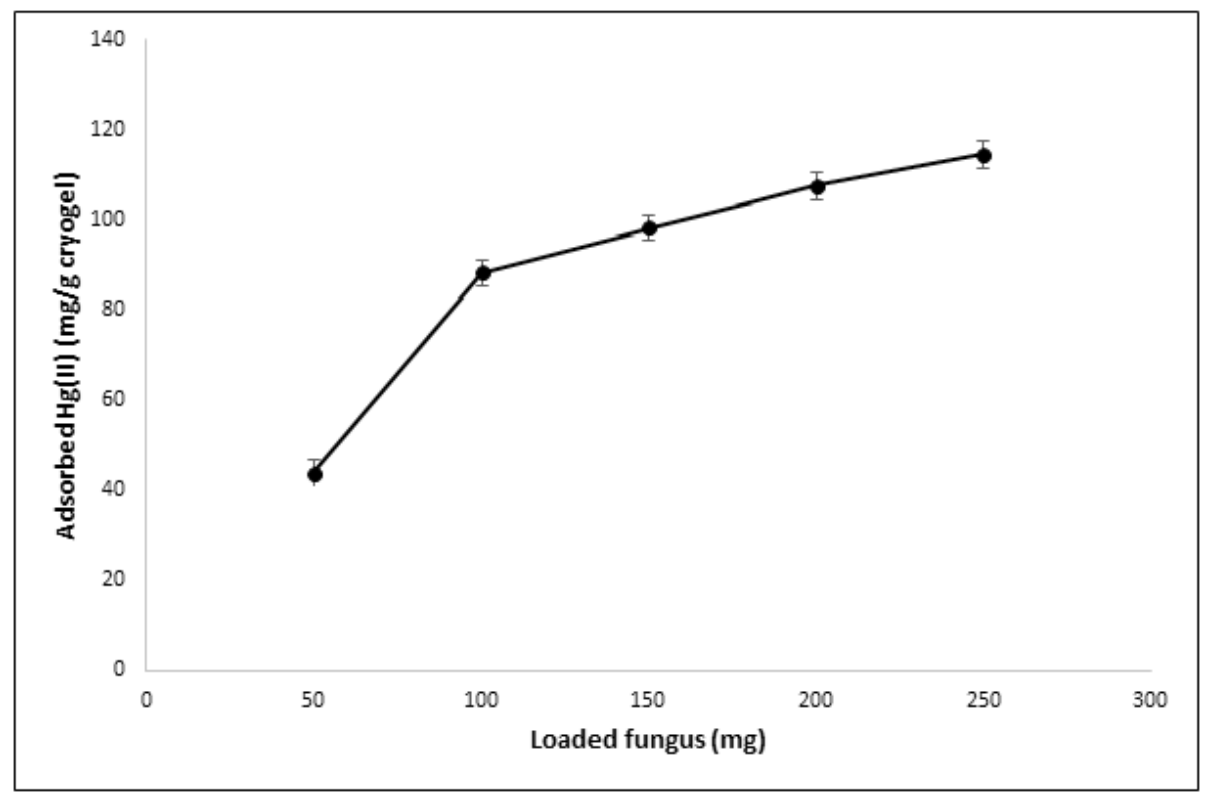

Figure 2. Effects of loaded fungus amount on biosorption of $\mathrm{Hg}^{2+}$ ions by Phanerochaete chrysosporium loaded cryogel column from aqueous solutions. Flow rate: $0.5 \mathrm{~mL} / \mathrm{min} \mathrm{pH}: 6.0 ; \mathrm{Hg}^{2+}$ concentration: $100 \mathrm{mg} / \mathrm{L} ; \mathrm{T}: 25^{\circ} \mathrm{C}$. 
onto the biosorption capacity of fungus loaded PHEMA cryogel column and plain PHEMA cryogel column are demonstrated in Figure $3 . \mathrm{Hg}^{2+}$ biosorption capacity of the fungus loaded cryogel column firstly increased with the increase in equilibrium concentration of $\mathrm{Hg}^{2+}$. As discussed in literature, it is claimed that this increase can be a result of an increase in electrostatic interactions (relative to covalent interactions), fungus' sites that shows progressively lower affinity for metal ions $[17,18]$. Then the biosorption capacity reached a stable value at around an equilibrium $\mathrm{Hg}^{2+}$ concentration of $100 \mathrm{mg} / \mathrm{L}$, which means reactive functional groups on the fungus particles were saturated with $\mathrm{Hg}^{2+}$. The maximum biosorption capacity was $88.2 \mathrm{mg} / \mathrm{g}$ of polymer. The results demonstrated that the $P$. chrysosporium loaded cryogel column has a higher binding capacity for $\mathrm{Hg}^{2+}$ than those of the plain cryogel $(4.2 \mathrm{mg} / \mathrm{g})$. Because of carboxyl and phosphate groups on the cell wall, the cell wall of fungi is negatively charged [19]. During biosorption, coordination complex was formed by these negative charged groups of the $P$. chrysosporium and $\mathrm{Hg}^{2+}$ ions in the solution. Furthermore, there is no specific binding groups on PHEMA for metal ion due to inert structure. It should be noted that a negligible amount of $\mathrm{Hg}^{2+}$ biosorbed nonselectively on the plain cryogel structure.

\section{Effect of pH Change}

In metal biosorption, the various mechanisms including complexation, coordination, adsorption, and microprecipitation may take roles separately or even synergistically $[20,21]$. Because one of the main interactions between fungi and metal ions is coordinate bonds, the medium pH is one of the most important factor governing metal biosorption in the biosorbent [22]. In literature, the theoretical and the experimental precipitation curves of mercury ions showed that precipitation (i.e. mercury hydroxides) begins above $\mathrm{pH} 8.0$ [23]. The effect of $\mathrm{pH}$ on $\mathrm{Hg}^{2+}$ biosorption by the cryogel column was studied at different $\mathrm{pH}$ values in the range of 2.0-7.0 as shown in Fig. 4. Biosorption rate of $\mathrm{Hg}^{2+}$ ions varied with different $\mathrm{pH}$ values in a coordination complex since metal ion acts as a Lewis acid, and the ligands, i.e. negatively charged groups on the fungus, act as Lewis bases. Figure 4 presents that higher biosorption values were obtained at higher $\mathrm{pH}$ values. The underlying logic of this statement is that proton in the medium acts as a competitor ion with the $\mathrm{Hg}^{2+}$ ions to form a coordination complex with the biosorption sites on the fungus. As the $\mathrm{pH}$ of the solution increases, the functional group of the fungus are deprotonated and negatively charged, which means that $\mathrm{Hg}^{2+}$ ions can bind to these groups at a higher amount $[17,24]$.

\section{Effect of flow rate}

The biosorption amounts of $\mathrm{Hg}^{2+}$ at different flow-rates are presented in Figure 5. Results showed that increment of the flow-rate through the column caused a decrement in the $\mathrm{Hg}^{2+}$ biosorption capacity by fungus loaded cryogel column. The amount of biosorbed $\mathrm{Hg}^{2+}$ decreased significantly from $88.2 \mathrm{mg} / \mathrm{g}$ to $74.1 \mathrm{mg} / \mathrm{g}$ polymer with the increase of the flow-rate from $0.5 \mathrm{~mL} /$ $\mathrm{min}$ to $4.0 \mathrm{~mL} / \mathrm{min}$. Similar results were observed in the literature [25-28]. It is an expected result because contact time between the $\mathrm{Hg}^{2+}$ ions and the fungus particles is longer at lower flow-rates $[29,30]$. Therefore, $\mathrm{Hg}^{2+}$ ions have more time to be able to form a coordination complex with active sites of the fungus; thus a higher biosorption amount is obtained.

\section{Regeneration and Reuse}

The regeneration of the column is one of the considering factors for commercial applications. In order to investigate the stability and reusability of the P. chrysosporium loaded PHEMA cryogel columns, the biosorption-elution cycle was repeated ten times using the same cryogel column. During elution process, elution agent $\mathrm{HNO}_{3}$ disrupts the coordination spheres of chelated $\mathrm{Hg}^{2+}$ ions and then $\mathrm{Hg}^{2+}$ ions were released from the cryogel matrix into the elution medium [24]. As it is expressed in Figure 6, there was no significant loss in the biosorption capacity of the cryogel column after the regeneration process.

\section{Biosorption from Artificial Wastewater}

Table 2 indicates that biosorption capacities of the P. chrysosporium loaded PHEMA cryogel columns from artificial wastewater. The biosorption 


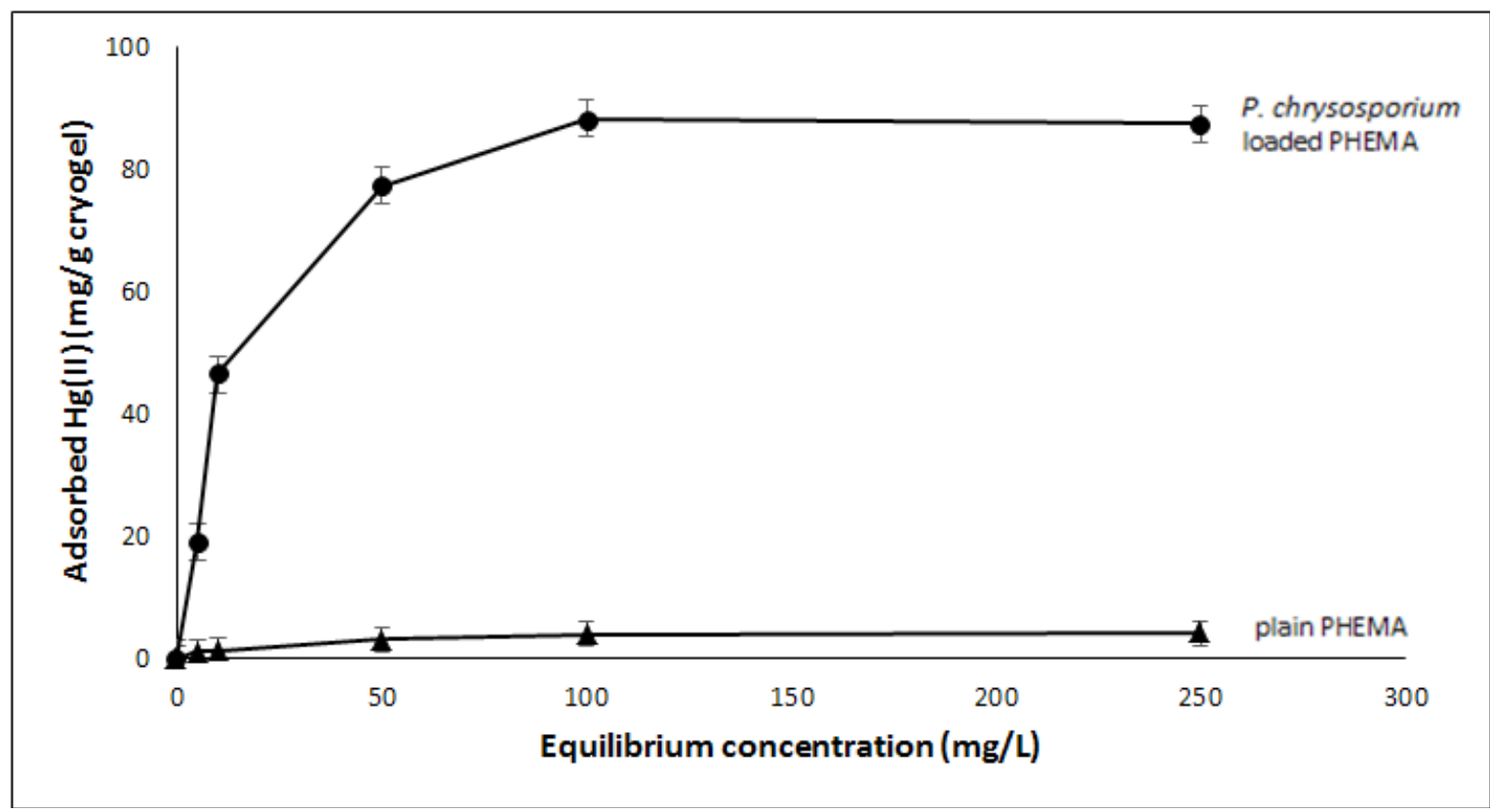

Figure 3. Effect of equilibrium $\mathrm{Hg}^{2+}$ concentration on biosorption of $\mathrm{Hg}^{2+}$ ions by Phanerochaete chrysosporium loaded cryogel column from aqueous solutions. Flow rate: $0.5 \mathrm{~mL} / \mathrm{min} \mathrm{pH:} 6.0 ; \mathrm{T}: 25^{\circ} \mathrm{C}$.

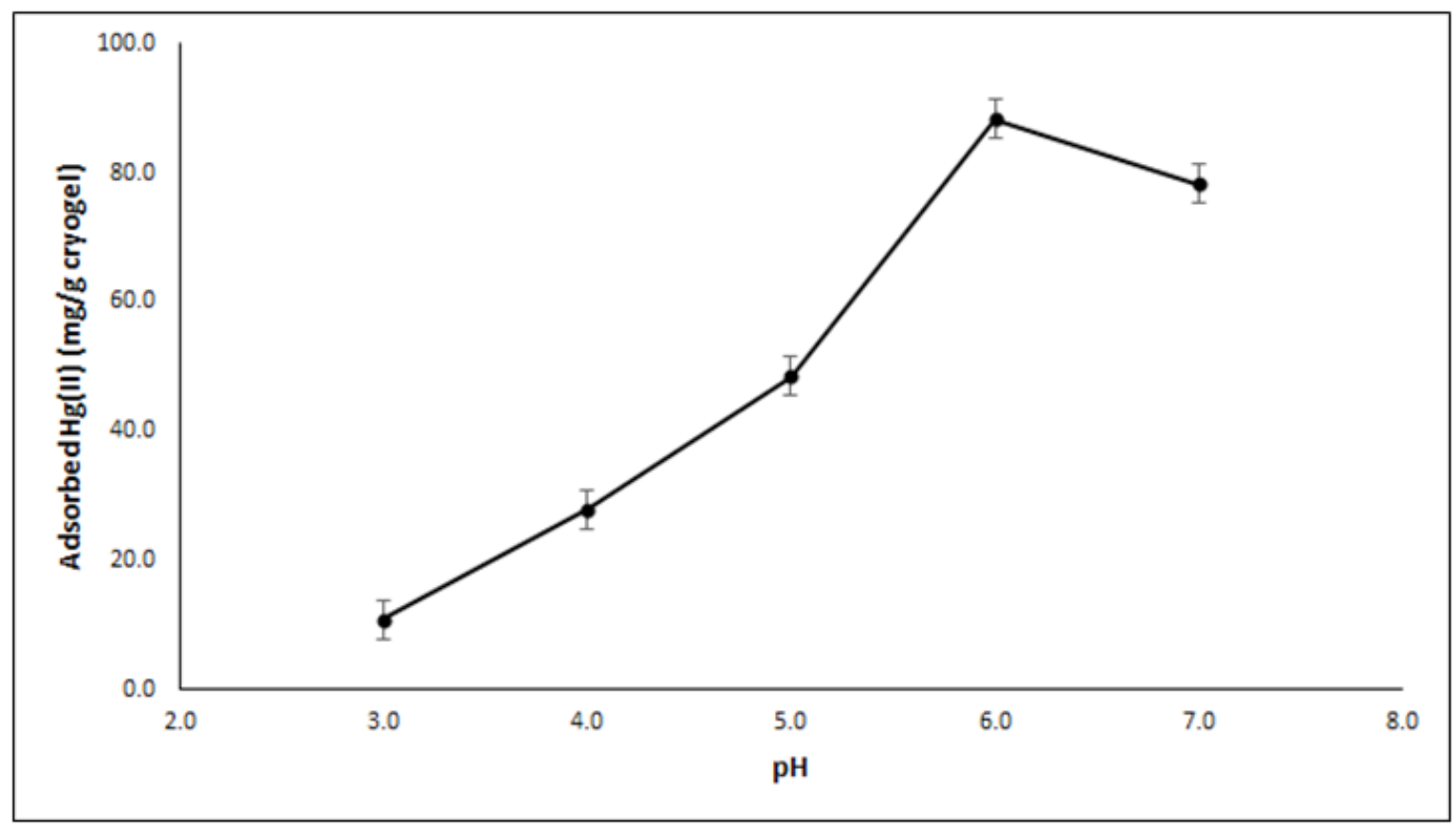

Figure 4. Effect of medium $\mathrm{pH}$ on $\mathrm{Hg}^{2+}$ biosorption by the cryogel column. Flow rate: $0.5 \mathrm{~mL} / \mathrm{min} \mathrm{pH}: 6.0 ; \mathrm{T}: 25^{\circ} \mathrm{C}$. 


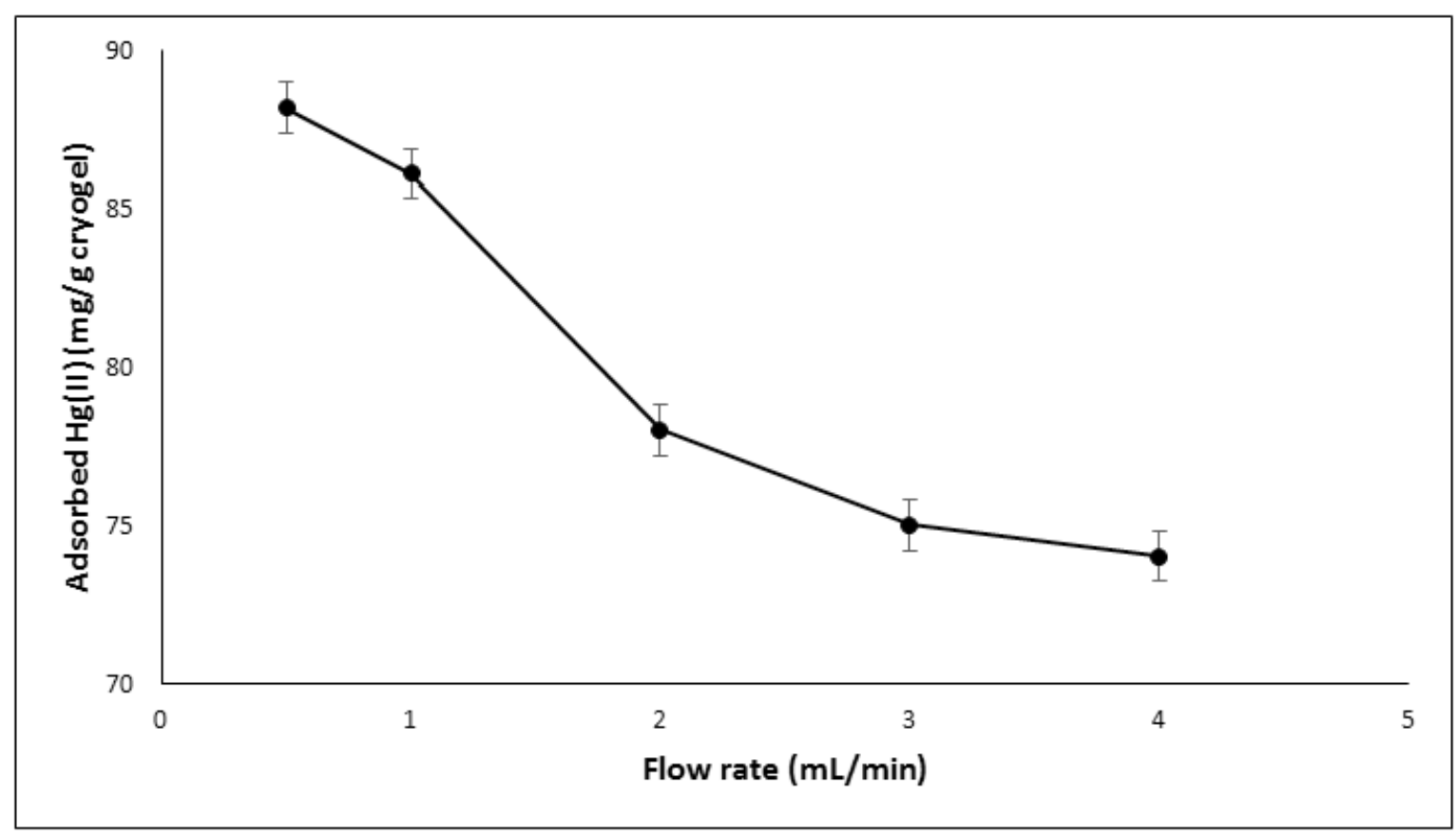

Figure 5. Effect of flow-rate onto the biosorption amount. $\mathrm{Hg}^{2+}$ concentration: $100 \mathrm{mg} / \mathrm{L} ; \mathrm{pH}: 6.0 ; \mathrm{T}: 25^{\circ} \mathrm{C}$.

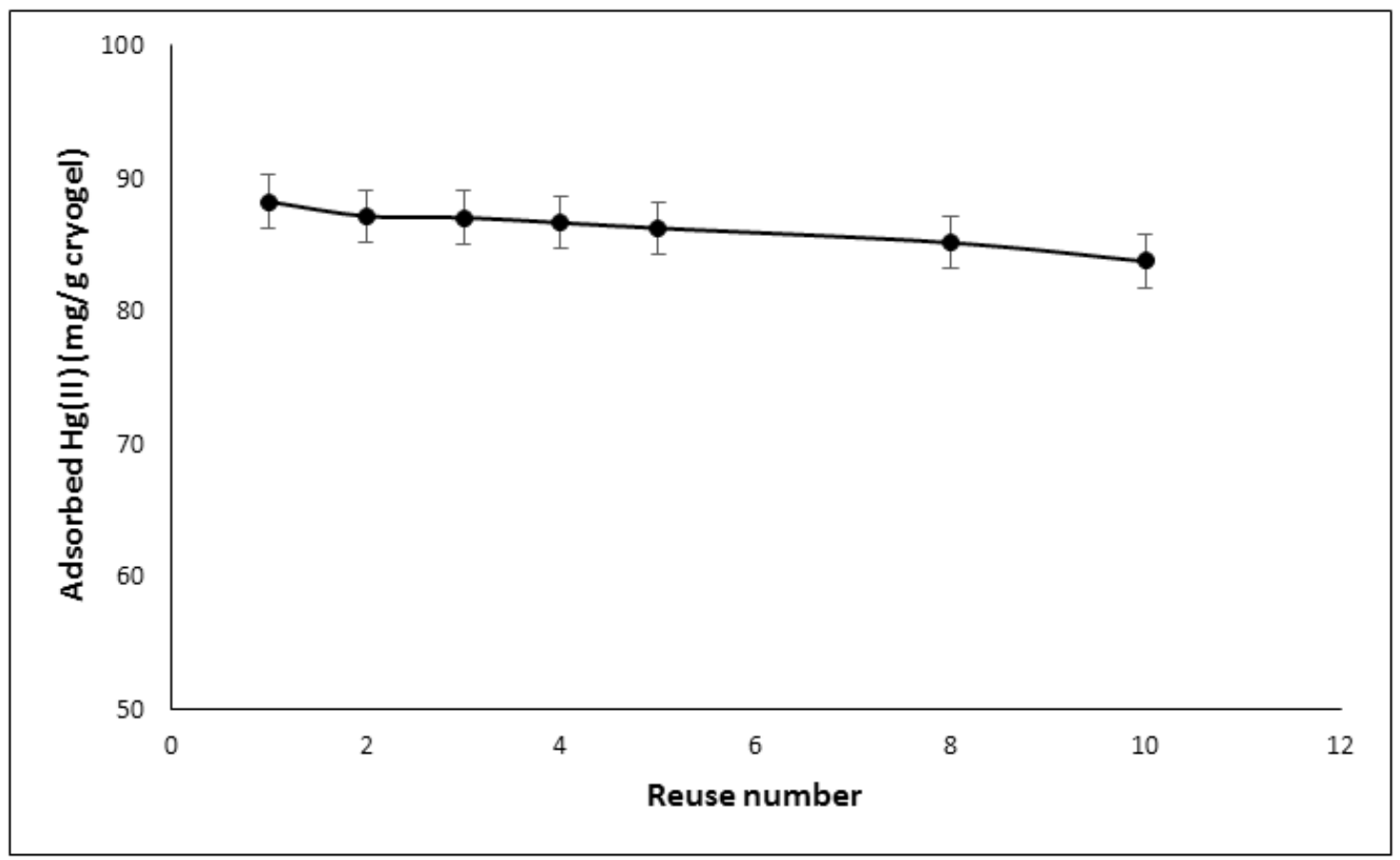

Figure 6. Biosorption-elution cycles for $\mathrm{Hg}^{2+}$; Flow rate: $0.5 \mathrm{~mL} / \mathrm{min} ; \mathrm{pH}: 6.0 ; \mathrm{Hg}^{2+}$ concentration: $100 \mathrm{mg} / \mathrm{L} ; \mathrm{T}: 25^{\circ} \mathrm{C}$. 
Table 2. Biosorption of heavy metal ions from artificial wastewater on the $P$. chrysosporium loaded PHEMA cryogel: Concentration of each metal ions: $1.0 \mathrm{mmol} / \mathrm{L}$; Flow rate: $0.5 \mathrm{ml} / \mathrm{min} ; \mathrm{pH}: 6.0$; adsorption time: $100 \mathrm{~min}$.

\begin{tabular}{cc}
\hline Ions & Biosorption (mg/g) \\
\hline $\mathrm{Hg}^{2+}$ & $75.22( \pm 2.04)$ \\
\hline $\mathrm{Cu}^{2+}$ & $24.15( \pm 1.13)$ \\
\hline $\mathrm{Ni}^{2+}$ & $12.91( \pm 0.85)$ \\
\hline $\mathrm{Zn}^{2+}$ & $7.85( \pm 0.74)$ \\
\hline $\mathrm{Fe}^{2+}$ & $5.59( \pm 0.62)$ \\
\hline $\mathrm{Cd}^{2+}$ & $16.86( \pm 0.92)$ \\
\hline $\mathrm{Co}^{2+}$ & $5.30( \pm 0.54)$ \\
\hline $\mathrm{Cr}^{3+}$ & $7.28( \pm 0.45)$ \\
\hline $\mathrm{Al}^{3+}$ & $2.97( \pm 0.52)$ \\
\hline
\end{tabular}

capacity of the composite cryogel column for $\mathrm{Hg}^{2+}$ from artificial wastewater was found $150.44 \pm 3.36$ $\mathrm{mg} / \mathrm{g}$. It is clear that the presence of other metal ions causes a decrease in the biosorption capacity of the P. chrysosporium loaded PHEMA cryogel for $\mathrm{Hg}^{2+}$ owing to competitive effect of the metal ions. However, it is a relatively small decrement in synthetic wastewater if compared with the biosorption capacity in single solutions.

\section{Conclusion}

Biosorption is the removal of substances, such as metal ions or metal containing species from solution investigated by biological material or bioproducts including fungi, yeast, bacteria, and algae via physicochemical binding [31-33]. In recent years, biosorption has gaining important role for removing heavy metals from aquatic systems [5]. In this study, we designed monolithic cryogel composite columns loaded with $P$. chrysosporium to remove $\mathrm{Hg}^{2+}$ ions from aqueous solutions. One of the most unique properties of cryogels is their macroporosity providing low back pressure even though particle is loaded in the cryogel matrix. Dead $P$. chrysosporium is preferred due to no need nutrition and controlling of concentration of biomass. The biosorption of $\mathrm{Hg}^{2+}$ ions on the cryogel column depends on the experimental conditions particularly medium $\mathrm{pH}$ and the equilibrium concentration of $\mathrm{Hg}^{2+}$ ions in the medium. As compared with the control columns (i.e. plain PHEMA columns), P. chrysosporium loaded PHEMA cryogel columns showed much more biosorption capacity for mercury ions. Repeated biosorption and elution cycles denoted the feasibility of the $P$. chrysosporium loaded PHEMA cryogel columns for $\mathrm{Hg}^{2+}$ biosorption.

\section{ACKNOWLEDGEMENTS}

K. Çetin thanks to The Scientific and Technological Research Council of Turkey (TUBITAK) for funding Ph.D. fellowship supplied by Science Fellowships and Grant Programs Department (BIDEB).

\section{References}

1. P.A. Ariya, M. Amyot, A. Dastoor, D. Deeds, A. Feinberg, G. Kos, A. Poulain, A. Ryjkov, K. Semeniuk, M. Subir, K. Toyota, Mercury physicochemical and biogeochemical transformation in the atmosphere and at atmospheric interfaces: A review and future directions, Chem. Rev., 115 (2015) 3760-3802.

2. C.T. Driscoll, Y.-J. Han, C.Y. Chen, D.C. Evers, K.F. Lambert, T. M. Holsen, N.C. Kamman, R.K. Munson, Mercury contamination in forest and freshwater ecosystems in the Northeastern United States, BioScience, 57 (2007) 17-28.

3. B.M. Johnson, J.M. Lepak, B.A. Wolff, Effects of prey assemblage on mercury bioaccumulation in a piscivorous sport fish, Sci. Total Environ., 506-507 (2015) 330-337.

4. H. Yavuz, A. Denizli, H. Güngüneş, M. Safarikova, I. Safarik, Biosorption of mercury on magnetically modified yeast cells, Sep. Purif. Technol., 52 (2006) 253-260.

5. F. Veglio', F. Beolchini, Removal of metals by biosorption: A review, Hydrometallurgy, 44 (1997) 301-316.

6. R.H. S. F. Vieira, B. Volesky, Biosorption: a solution to pollution?, Int. Microbiol., 3 (2000) 17-24.

7. Y. Kaçar, Ç. Arpa, S. Tan, A. Denizli, Ö. Genç, M.Y. Arıca, Biosorption of $\mathrm{Hg}(\mathrm{II})$ and $\mathrm{Cd}(\mathrm{II})$ from aqueous solutions: comparison of biosorptive capacity of alginate and immobilized live and heat inactivated Phanerochaete chrysosporium, Process. Biochem., 37 (2002) 601-610. 
8. A. Kapoor, T. Viraraghavan, D.R. Cullimore, Removal of heavy metals using the fungus Aspergillus niger Bioresource Technol., 70 (1999) 95-104.

9. C.P. Huang, D. Westman, K. Quirk, J.P. Huang, The removal of cadmium(II) from dilute aqueous solution by fungal adsorbent, Water Sci. and Technol., 20 (1988) 369-376.

10. M. Andaç, A. Denizli, Affinity-recognition-based polymeric cryogels for protein depletion studies, RSC Adv., 4 (2014) 31130-31141.

11. F.M. Plieva, I.Y. Galaev, W. Noppe, B. Mattiasson, Cryogel applications in microbiology, Trends in Microbiol., 16 (2008) 543-551.

12. E. Jain, A. Kumar, Disposable polymeric cryogel bioreactor matrix for therapeutic protein production, Nat. Protoc., 8 (2013) 821-835.

13. N. Bereli, Y. Saylan, L. Uzun, R. Say, A. Denizli, L-Histidine imprinted supermacroporous cryogels for protein recognition, Sep. Purif. Technol., 82 (2011) 28-35.

14. V.I. Lozinsky, I.Y. Galaev, F.M. Plieva, I.N. Savina, H. Jungvid, B. Mattiasson, Polymeric cryogels as promising materials of biotechnological interest, Trends in Biotechnol., 21 (2003) 445-451.

15. P. Arvidsson, F.M. Plieva, V.I. Lozinsky, I.Y. Galaev, B. Mattiasson, Direct chromatographic capture of enzyme from crude homogenate using immobilized metal affinity chromatography on a continuous supermacroporous adsorbent, J. Chromatogr. A, 986 (2003) 275-290.

16. L. Uzun, C. Armutcu, Ö. Biçen, A. Ersöz, R. Say, A. Denizli, Simultaneous depletion of immunoglobulin $G$ and albumin from human plasma using novel monolithic cryogel columns, Colloids Surf. B, 112 (2013) 1-8.

17. M. Iqbal, R.G.J. Edyvean, Biosorption of lead, copper and zinc ions on loofa sponge immobilized biomass of Phanerochaete chrysosporium, Miner. Eng., 17 (2004) 217-223.

18. S. Al-Asheh, Z. Duvnjak, Adsorption of Copper and Chromium by Aspergillus carbonarius, Biotechnol. Prog., 11 (1995) 638-642.

19. J.M. Tobin, C. White, G.M. Gadd, Metal accumulation by fungi: application in environmental biotechnology, J. Ind. Microbiol., 13 (1994) 126-130.

20. M.Z. Hu, J.M. Norman, B.D. Faison, M.E. Reeves, Biosorption of uranium by pseudomonas aeruginosa strain CSU: Characterization and comparison studies, Biotechnol. Bioeng., 51 (1996) 237-247.

21. P.R. Puranik, K.M. Paknikar, Biosorption of lead, cadmium, and zinc by citrobacter strain MCM B-181: Characterization studies, Biotechnol. Prog., 15 (1999) 228-237.
22. E. Pehlivan, B.H. Yanık, G. Ahmetli, M. Pehlivan, Equilibrium isotherm studies for the uptake of cadmium and lead ions onto sugar beet pulp, Bioresource Technol., 99 (2008) 3520-3527.

23. M. Šafaríková, L. Ptáková, I. Kibriková, I. Šafarík, Biosorption of water-soluble dyes on magnetically modified Saccharomyces cerevisiae subsp. uvarum cells, Chemosphere, 59 (2005) 831-835.

24. M.Y. Arıca, Ç. Arpa, B. Kaya, S. Bektaş, A. Denizli, Ö. Genç, Comparative biosorption of mercuric ions from aquatic systems by immobilized live and heatinactivated Trametes versicolor and Pleurotus sajurcaju, Bioresource Technol., 89 (2003) 145-154.

25. S. Büyüktiryaki, R. Say, A. Ersöz, E. Birlik, A. Denizli, Selective preconcentration of thorium in the presence of $\mathrm{UO}_{2}{ }^{2+}, \mathrm{Ce}^{3+}$ and $\mathrm{La}^{3+}$ using Th(IV)-imprinted polymer, Talanta, 67 (2005) 640-645.

26. M. Karataş, S. Akgöl, H. Yavuz, R. Say, A. Denizli, Immunoglobulin $\mathrm{G}$ depletion from human serum with metal-chelated beads under magnetic field, Int. J. Biol. Macromol., 40 (2007) 254-260.

27. J. Wu, H.Q. Yu, Biosorption of 2,4-dichlorophenol from aqueous solutions by immobilized Phanerochaete chrysosporium biomass in a fixed-bed column, Chem. Eng. J., 138 (2008) 128-135.

28. J. Cruz-Olivares, C. Pérez-Alonso, C. Barrera-Díaz, F. Ureña-Nuñez, M.C. Chaparro-Mercado, B. Bilyeu, Modeling of lead (II) biosorption by residue of allspice in a fixed-bed column, Chem. Eng. J., 228 (2013) 21-27.

29. i. Koç, G. Baydemir, E. Bayram, H. Yavuz, A. Denizli, Selective removal of $17 \beta$-estradiol with molecularly imprinted particle-embedded cryogel systems, J. Hazard. Mater. 192 (2011) 1819-1826.

30. F.M. Plieva, M. Karlsson, M.R. Aguilar, D. Gomez, S. Mikhalovsky, I.Y. Galaev, Pore structure in supermacroporous polyacrylamide based cryogels, Soft Matter, 1 (2005) 303-309.

31. D. Bulgariu, L. Bulgariu, Equilibrium and kinetics studies of heavy metal ions biosorption on green algae waste biomass, Bioresource Technol., 103 (2012) 489-493.

32. Y.A. Yahaya, M.M. Don, Pycnoporus sanguineus as Potential Biosorbent for Heavy Metal Removal from Aqueous Solution: A Review, J. Phys. Sci., 25 (2014) 1-32.

33. M. Fomina, G.M. Gadd, Biosorption: current perspectives on concept, definition and application, Bioresource Technol., 160 (2014) 3-14. 